\title{
Studies on the Stability of Anodic Oxides on Zirconium Biocompatible Alloys
}

\author{
Nilson T. C. Oliveira, Sonia R. Biaggio*, Romeu C. Rocha-Filho and Nerilso Bocchi \\ Departamento de Química, Universidade Federal de São Carlos, CP 676, 13560-970 São Carlos - SP, Brazil
}

\begin{abstract}
Estudos sobre a estabilidade de óxidos anódicos crescidos sobre zircônio e suas ligas biocompatíveis Ti-50Zr \%at. e Zr-2,5Nb \%m., em solução fisiológica de Ringer aerada, a 25 e $37^{\circ} \mathrm{C}$, foram feitos por meio da comparação entre as cargas de sua formação e de sua reconstrução após dissolução a circuito aberto na solução fisiológica. A estabilidade de óxidos crescidos na solução de Ringer e em solução de $\mathrm{Na}_{2} \mathrm{SO}_{4} 0,15 \mathrm{~mol} \mathrm{~L}^{-1}$ foi comparada. Os resultados obtidos mostram que a estabilidade desses óxidos é aumentada por envelhecimento sob condições potenciostáticas e que ela pode ser decrescida pela presença de íons cloreto no eletrólito durante o processo de anodização.
\end{abstract}

Studies on the stability of anodic oxides grown on zirconium and its biocompatible alloys Ti$50 \mathrm{Zr}$ at. $\%$ and $\mathrm{Zr}-2.5 \mathrm{Nb}$ wt.\%, in aerated Ringer physiological solution, at 25 and $37{ }^{\circ} \mathrm{C}$, were carried out by comparing their formation charge and their reconstruction charge after dissolution at open circuit in the physiological solution. The stability of oxides grown in the Ringer solution and in a $0.15 \mathrm{~mol} \mathrm{~L}^{-1} \mathrm{Na}_{2} \mathrm{SO}_{4}$ solution was compared. The obtained results show that the stability of these oxides is increased by aging under potentiostatic conditions and can be decreased by the presence of chloride ions in the electrolyte during the anodization process.

Keywords: zirconium, zirconium alloys, anodic oxides, passivation

\section{Introduction}

Elements such as $\mathrm{Zr}$, $\mathrm{Ti}$ and $\mathrm{Nb}$, which belong to a group known as valve metals, usually have their surfaces covered by a thin oxide film spontaneously formed in air or in electrolytes at open circuit. ${ }^{1,2}$ This film constitutes a barrier between metal and medium. Typical values of the initial thickness of these oxide films are in the range 2-5 $\mathrm{nm}$, when formed in air at room temperature, but the thickness of the films can be increased by anodic oxidation. ${ }^{1-3}$ For anodic films on valve metals, the thickness is determined by the applied potential and may be estimated from the anodization rate, which typically lies in the range $1.0-2.0 \mathrm{~nm} \mathrm{~V}^{-1}$. 2,4,5 The growth of these anodic films, commonly irreversible, occurs with a fixed stoichiometry under an electrical field strength $E$ of $10^{6}$ $10^{7} \mathrm{~V} \mathrm{~cm}^{-1}$, the current density $j$ being described by the high-field (or constant-field) growth model:

$j=A \exp (\beta E)$

where $A$ and $\beta$ are material dependent constants. ${ }^{25,6}$

* e-mail: biaggio@ power.ufscar.br
Currently, with the increase of the population of over 65 years old persons, in countries such as Japan, United States, Germany etc, the need for the use of artificial implants is also increasing, making necessary more thorough studies on materials that may be used for such an end. ${ }^{7-9} \mathrm{~A}$ live organism, containing saline solutions, is considered to be a corrosive medium for several materials. Due to the high corrosion resistance of some valve metals $(\mathrm{Zr}, \mathrm{Ti}, \mathrm{Nb}$, $\mathrm{W}, \mathrm{Ta}$ ) in different highly-corrosive environments, mainly those of an oxidative nature or containing chlorides, the field for application of these metals and their alloys was naturally enlarged, allowing rapid and significant advances in the areas of medical instrumentation and surgical implants. ${ }^{10,11}$ Considering that some $\mathrm{Zr}$ and $\mathrm{Ti}$ alloys present, among other qualities, excellent mechanical properties, very good corrosion resistance, biocompatibility, and good durability, they become interesting and promising materials for use in implants. ${ }^{12}$

The combination of $\mathrm{Zr}$ with $\mathrm{Nb}$ made possible the development of a structure that supposedly presents a high corrosion resistance but continues having the mechanical resistance necessary for implants. ${ }^{13}$ Binary Ti-Zr alloys have been studied so as to evaluate their possible use for biomedical purposes. Zirconium and titanium have similar chemical properties and $\mathrm{Zr} / \mathrm{Ti}$ systems show a complete 
solubility at both low and high temperatures; ${ }^{14}$ thus several alloys with different amounts of these elements were investigated. Tensile strength as well as hardness tests revealed that the alloy with equal atomic amounts of each element presented the best results, ${ }^{12}$ with hardness and tensile strength 2.5 times greater than those of pure $\mathrm{Zr}$ and pure Ti.

Taking into account the possible use in implants in the human body and that there are very few electrochemical studies on these alloys, ${ }^{15}$ this work aimed to study the growth and stability of anodic-oxide films that passivate the alloys $\mathrm{Zr}-2.5 \mathrm{Nb}$ wt.\% and $\mathrm{Ti}-50 \mathrm{Zr}$ at.\%, in a electrolyte that simulates the physiological medium (Ringer solution), at 25 and $37{ }^{\circ} \mathrm{C}$. The results obtained with the help of electrochemical techniques (linear voltammetry and chronoamperometry) were compared with those for oxides grown on pure $\mathrm{Zr}$ under the same conditions.

\section{Experimental}

The alloys used in the present work, Ti-50Zr at.\% and $\mathrm{Zr}-2.5 \mathrm{Nb}$ wt $\%$, were prepared by fusion in a voltaic arc (under inert atmosphere) from the pure metals: $\mathrm{Zr}$ (Johnson Matthey, 99.8\%), Nb (Degussa, 99.8\%) and Ti (Müller Metals - Brazil, $99.7 \%$ ), following a procedure described by Kobayashi et $a l .{ }^{12}$ After the fusion, the alloys were characterized by metallography and by inductively coupled plasma - atomic emission spectroscopy (ICP-AES). Previous to any anodic oxide growth, the working electrodes were polished with silicon carbide paper of grade 600 and rinsed with bidistilled water. A saturated calomel electrode (SCE) was used as reference and a $2 \mathrm{~cm}^{2} \mathrm{Pt}$ foil was used as counter electrode. A Ringer physiological solution $\left(8.61 \mathrm{~g} \mathrm{~L}^{-1} \mathrm{NaCl}, 0.49 \mathrm{~g} \mathrm{~L}^{-1}\right.$ $\mathrm{CaCl}_{2}, 0.30 \mathrm{~g} \mathrm{~L}^{-1} \mathrm{KCl}$ ) was used as electrolyte, kept at either 25 or $37^{\circ} \mathrm{C}$. A conventional three-electrode cell with a jacket for temperature control was used in all electrochemical experiments.

The experimental procedure used in the studies on the oxide stability has been described elsewhere ${ }^{3}$ and was carried out using an Ecochemie/Autolab potentiostat/ galvanostat, model PGSTAT 20. The electrochemical method used (here referred as $\mathrm{LV}_{1}$ ) consisted of a linear potential scan $\left(v=50 \mathrm{mV} \mathrm{s}^{-1}\right)$ starting at a potential in the hydrogen evolution region up to a final potential $\left(E_{\mathrm{F}}\right)$ in the anodic region; then the oxide formed was aged by keeping the system polarized at $E_{\mathrm{F}}$ while the variation of the current with time was followed (chronoamperometry). When the current reached an approximately constant value, the circuit was opened and the potential vs. time profile was followed until a constant value was reached. Finally, to reconstruct the oxide eventually corroded in the previous step, a new linear potential scan similar to the first one was carried out. The potential-time programme for this procedure can be seen in Figure 1(a). This method was repeated for different $E_{\mathrm{F}}$ values in the passive region previously assesed. ${ }^{16}$ An alternative method was also used (hereinafter referred as $\mathrm{LV}_{2}$ ), consisting of method $\mathrm{LV}_{1}$ without the oxide-aging step.

In complementary studies, the anodic oxides were grown on the working electrode ( $\mathrm{Zr}$ and the two alloys) in a less aggressive electrolyte, i.e., in the absence of chloride

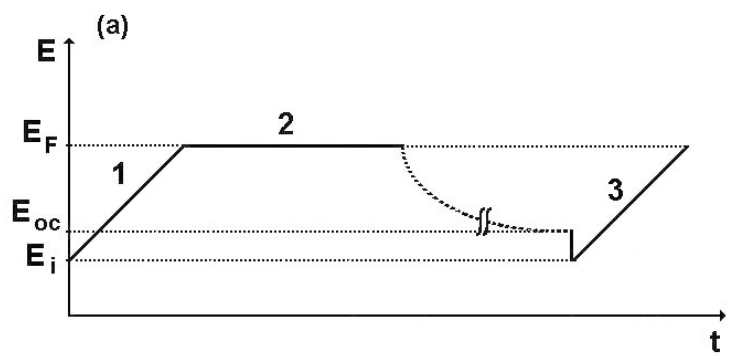

(b)

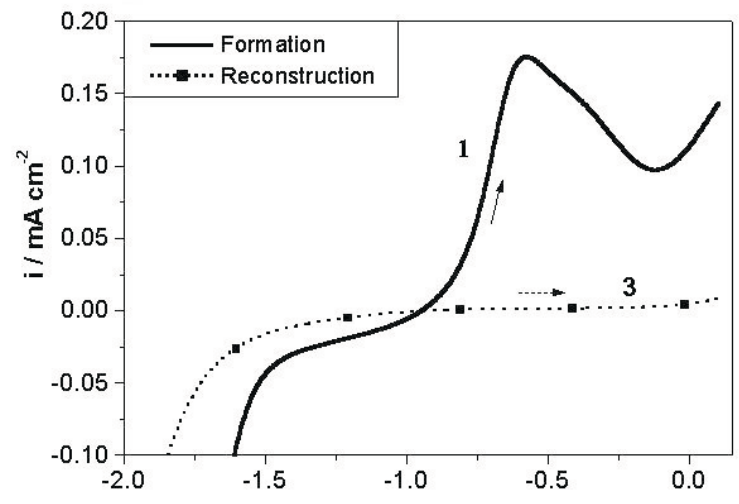

(c)

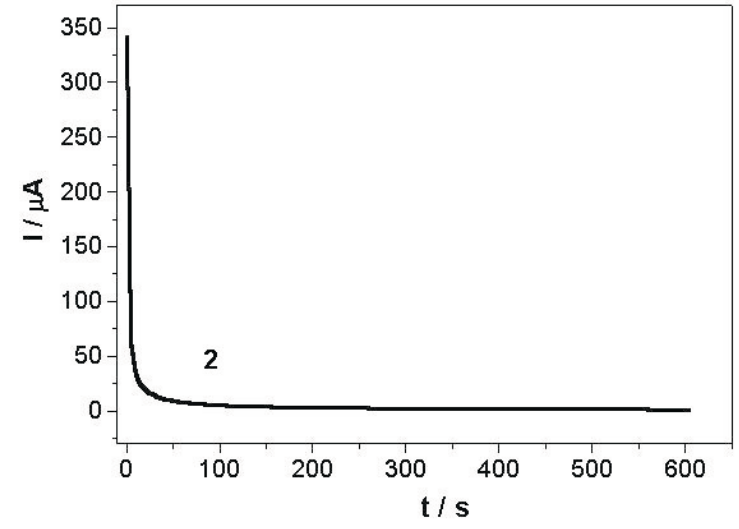

Figure 1. (a) Potential-time programme used in the $\mathrm{LV}_{1}$ method. (b) Linear voltammograms at $50 \mathrm{mV} \mathrm{s}^{-1}$ for the formation (curve 1) and reconstruction (curve 3) of the oxide film on $\mathrm{Zr}-2.5 \mathrm{Nb}$ wt.\% in the Ringer solution, at $25^{\circ} \mathrm{C}$, from $E_{i}=-1.8 \mathrm{~V}$ up to $E_{\mathrm{F}}=0.1 \mathrm{~V}(v s$. SCE). (c) Chronoamperometric curve corresponding to the aging of the same oxide at $E_{\mathrm{F}}$, immediately after its formation. 
ions; for such, a $0.15 \mathrm{~mol} \mathrm{~L}^{-1} \mathrm{Na}_{2} \mathrm{SO}_{4}$ solution was used. In these studies, after the oxide was grown and aged (according to method $\mathrm{LV}_{1}$ ), the working electrode was transferred to another electrochemical cell containing the Ringer solution and there left on open circuit until the stabilization of its potential. Then the working electrode was transferred back to the cell containing the $\mathrm{Na}_{2} \mathrm{SO}_{4}$ solution where a new linear voltammetry similar to the first one was carried out so as to reconstruct the oxide eventually corroded in the Ringer electrolyte.

\section{Results and discussion}

The results obtained in the electrochemical studies involving the growth and reconstruction of the oxide film on $\mathrm{Zr}$ and the two alloys in the Ringer solution using method $\mathrm{LV}_{1}$ led to similar voltammetric profiles. As an example, the oxide growth and reconstruction profiles on the $\mathrm{Zr}-2.5 \mathrm{Nb}$ wt. \% alloy, for $E_{\mathrm{F}}=0.1 \mathrm{~V}$ at $25^{\circ} \mathrm{C}$, are shown in Figure 1(b). The chronoamperometric profile obtained at $E_{\mathrm{F}}$ for this same system after film formation is shown in Figure 1(c). This profile shows that initially the current decreases rapidly, i.e. the oxide is passivating the alloy, and then slowly, until it becomes steady. This slow and continuing variation of the current is attributed to aging of the anodic oxide film, with possible dehydration and structural rearrangements due to the imposed electrical field. ${ }^{17-19}$ It is commonly assumed that this aging can make the oxide film more compact and more resistive, and thus can increase its corrosion resistance. ${ }^{3,20,21}$ As for the valve metals, the thickness of their anodic oxides increases in a direct proportion with the applied potential (according to the high-field growth model - equation 1), the very small charge due to the aging at $\mathrm{E}_{\mathrm{F}}$ can be neglected and, therefore, was not considered for the calculation of the electrical charge passed to grow the film, $Q_{\mathrm{F}}$.

After the anodic growth of the film (aged or not, depending on the case), the circuit was open so as to study the oxide film stability to spontaneous dissolution. Studies on the stability of oxides are commonly carried out by monitoring the potential at open circuit $\left(E_{\mathrm{oc}}\right)$ as a function of time, leading to a knowledge of the resting potential and the time taken to reach it. ${ }^{3}$ Once the resting potential is reached, the film is reconstructed. The dissolution process of valve-metal oxides at open circuit potential is still controversial, since the hydrolysis equilibrium is not obvious. Blackwood et al. ${ }^{22}$ have found that the spontaneous dissolution rate of $\mathrm{TiO}_{2}$, in sulfuric acid solutions of various $\mathrm{pH}$, is first order with respect to proton concentration. Thus, they proposed that the oxide hydrolysis might be written as:
$\mathrm{TiO}_{2}+\mathrm{H}_{2} \mathrm{O}+\mathrm{H}^{+} \rightarrow \mathrm{Ti}(\mathrm{OH})_{3}^{+}$

Should this be the case, a very slow chemical dissolution rate (and therefore very low reconstruction changes) should be expected for these oxides in the Ringer solutions (pH 6.8). From the voltammetric profiles for the growth and the reconstruction of the oxide it is possible, by determining the areas under the curves, to compare the magnitudes of these processes through the electrical charges $(Q)$ associated to them.

For the growth of the oxide films, the formation charge $\left(Q_{\mathrm{F}}\right)$ increases as $E_{\mathrm{F}}$ becomes more positive, as it is shown in Figure 2. The linear relationship found is consistent with the assumption that the oxide is growing according to the high-field growth model. On the other hand, from a comparison of the slopes of the plots $Q_{\mathrm{F}} v s$. $E_{\mathrm{F}}$ one clearly sees that the anodization rate ${ }^{3}$ is greater for the alloys than for $\mathrm{Zr}$, suggesting that the addition to zirconium of the alloying elements $\mathrm{Ti}$ and $\mathrm{Nb}$ (in the proportions indicated for each alloy) is affecting the anodic-oxide formation rate. Similar results were obtained at $37^{\circ} \mathrm{C}$.

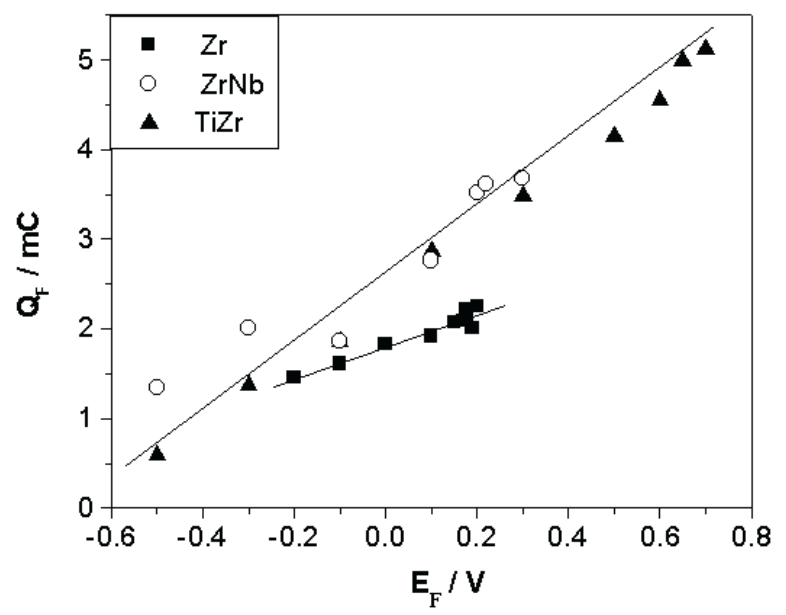

Figure 2. Formation charges $\left(Q_{\mathrm{F}}\right)$ as a function of the final formation potential $\left(E_{\mathrm{F}}\right)$ for the growth of oxide on $\mathrm{Zr}, \mathrm{Zr}-2.5 \mathrm{Nb}$ wt.\% and $\mathrm{Ti}-50 \mathrm{Zr}$ at. $\%$ in the Ringer solution, at $25{ }^{\circ} \mathrm{C}$.

From the oxide formation charges $\left(Q_{\mathrm{F}}\right)$ and reconstruction charges $\left(Q_{\text {rec }}\right)$, it is possible to grasp the importance of aging on the stability of the oxide anodically grown on the surface of $\mathrm{Zr}$ and its alloys. For such, the oxide film reconstruction rate $(R R)$ is defined ${ }^{3}$ as being equal to the ratio between $Q_{\text {rec }}$ and $Q_{\mathrm{F}}$. The percentage values of $R R$ for the oxides grown on $\mathrm{Zr}$ and its alloys using method $\mathrm{VL}_{1}$ are shown in Figure 3(a). Clearly there are two different behaviors. The Ti-50Zr at.\% alloy presents higher $R R$ values that generally increase as $E_{\mathrm{F}}$ becomes more negative, reaching a maximum value of around $11 \%$. 
(a)

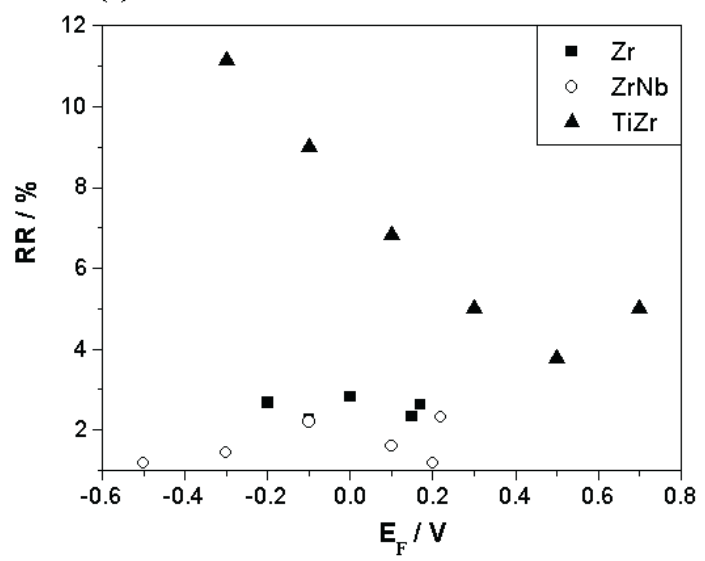

(b)

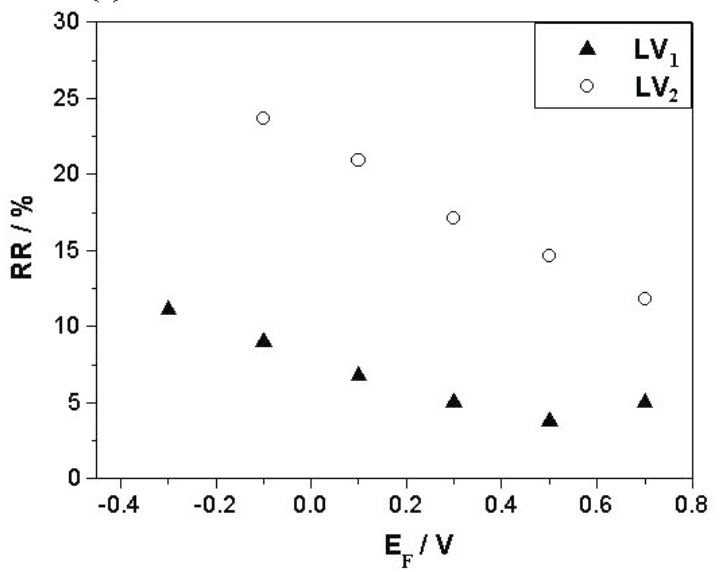

Figure 3. (a) Oxide reconstruction rates $(R R)$ as a function of the final formation potential $\left(E_{\mathrm{F}}\right)$ for the oxides grown and reconstructed on the different materials (as indicated in the figure) in the Ringer solution, at $25{ }^{\circ} \mathrm{C}$, using growth method $\mathrm{LV}_{1}$. (b) Influence of the growth method (as indicated in the figure) on the oxide reconstruction rates for oxides grown and reconstructed on $\mathrm{Ti}-50 \mathrm{Zr}$ at.\% in the Ringer solution, at $25{ }^{\circ} \mathrm{C}$.

Since the film thickness increases as $E_{\mathrm{F}}$ becomes more positive, it can be apprehended that the thicker films are more stable than the thinner ones. On the other hand, $\mathrm{Zr}$ and the $\mathrm{Zr}-2.5 \mathrm{Nb}$ wt.\% alloy present $R R$ values that are quite low, always smaller than $3 \%$, with no clear dependence on $E_{\mathrm{F}}$. The studies carried out at $37^{\circ} \mathrm{C}$ yielded similar results. Considering that the oxide growing potentials are not in the region where pit corrosion sets in, ${ }^{16}$ the fact that the $\mathrm{Ti}-50 \mathrm{Zr}$ at. $\%$ is presenting higher values of $R R$ may be due to mechanical instability of the grown oxide. Anodic oxides of titanium are prone to incorporate species from the electrolytic solution, ${ }^{23,24}$ which can lead to changes in the mechanical properties of the oxide. Usually oxides have a natural level of internal stress, but the presence of incorporated foreign species affects directly the ratio between the oxide molar volume and the metal molar volume, leading to alterations in the internal stress that may cause the rupture of the protecting oxide film. ${ }^{24-26}$ Figure 3(b) shows a comparison between $R R$ data for oxide films grown using methods $\mathrm{LV}_{1}$ (aged film) and $\mathrm{LV}_{2}$ (nonaged film) on the Ti-50Zr at.\% alloy. Clearly, the aging step has a significant influence on the stability of the oxide film, since reconstruction of the film is reduced to $50 \%$ or less compared to the one that occurs in the absence of the potentiostatic-aging step. Similar influence was found for $\mathrm{Zr}$ and the other alloy.

Figure 4 shows a comparison between $R R$ data for oxide films obtained at 25 and $37^{\circ} \mathrm{C}$, using method $\mathrm{LV}_{1}$. It can be seen, as it should be expected, that the increase in temperature causes an increase in the anodic-oxide dissolution rate. This effect should be taken into account when in vivo experiments are carried out.

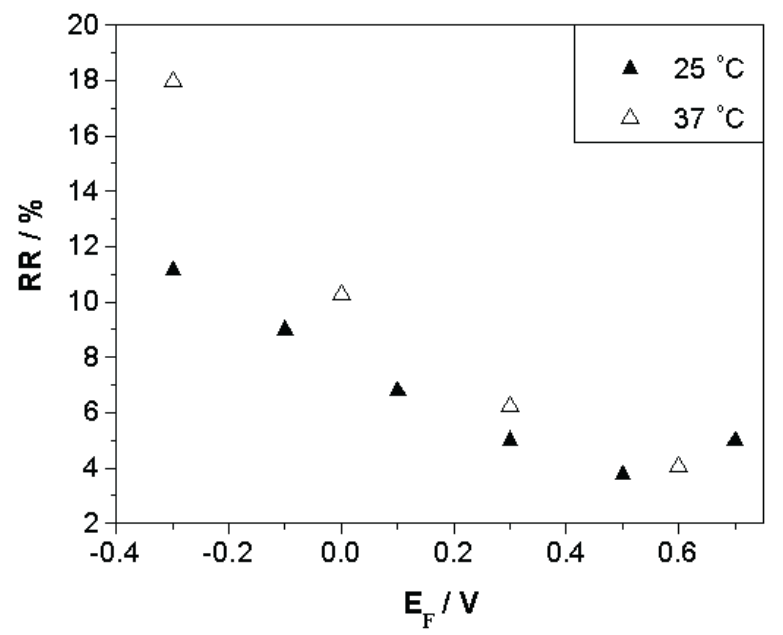

Figure 4. Oxide reconstruction rates $(R R)$ as a function of the final formation potential $\left(E_{\mathrm{F}}\right)$ for the oxides grown and reconstructed on Ti-50Zr at.\% in the Ringer solution, at different temperatures (as indicated in the figure), using growth method $\mathrm{LV}_{1}$.

Considering that the anodic growth of the oxide films in the Ringer solution is limited to a small potential range due to the presence of chloride ions in the electrolyte, which causes pitting, ${ }^{27}$ and, furthermore, that the very presence of these ions in the electrolyte may affect the passivating properties of the grown oxides, oxide films were grown on $\mathrm{Zr}$ and its alloys in a less aggressive electrolyte, ${ }^{28} 0.15 \mathrm{~mol} \mathrm{~L}^{-1} \mathrm{Na}_{2} \mathrm{SO}_{4}$, exposed to the Ringer solution and reconstructed in the $\mathrm{Na}_{2} \mathrm{SO}_{4}$ solution (see Experimental section). Taking the Ti-50Zr at.\% alloy as an example, Figure 5 presents the drastic changes in the $i / E$ profile with the presence or absence of $\mathrm{Cl}^{-}$ions during the anodic oxide growth. The current loop in the cathodic sweep and the current fluctuations in the passive region, 

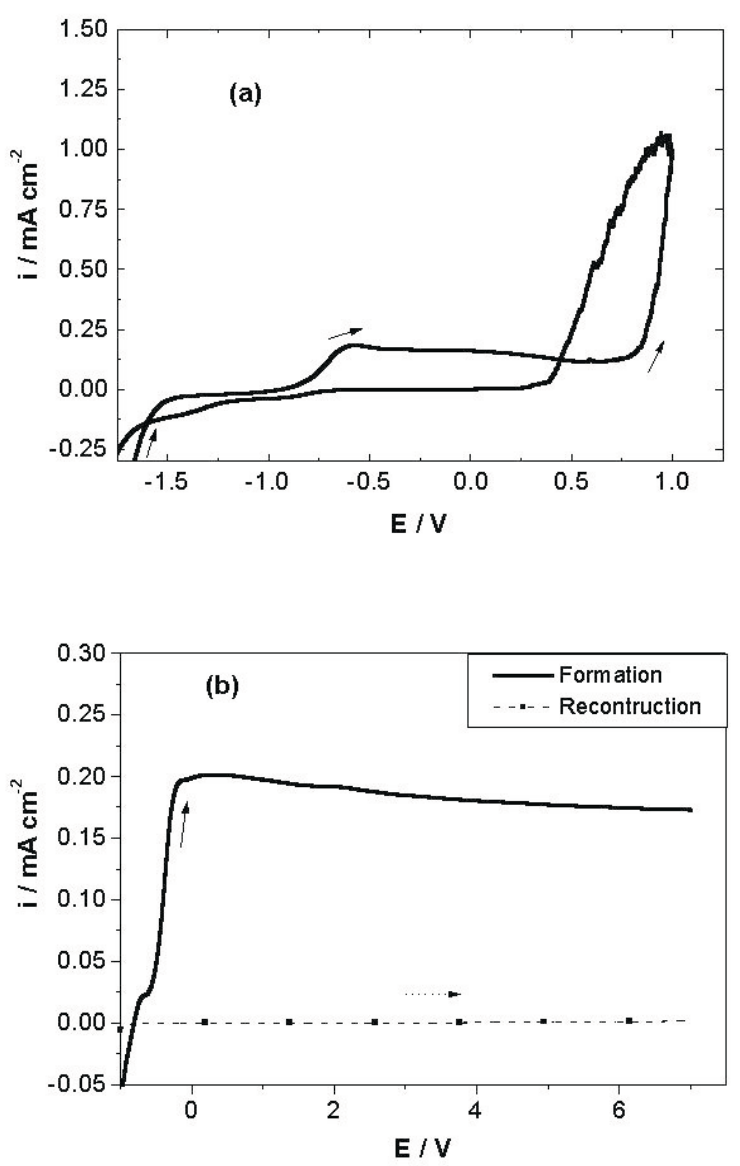

Figure 5. Voltammetries at $50 \mathrm{mV} \mathrm{s}{ }^{-1}$ and $25{ }^{\circ} \mathrm{C}$ for a Ti-50Zr at. $\%$ electrode: (a) in the Ringer solution; (b) in the $\mathrm{Na}_{2} \mathrm{SO}_{4}$ solution, showing the formation and reconstruction of the oxide film by method $\mathrm{LV}_{1}$.

seen in Figure 5(a), indicate that pitting corrosion processes are occurring and limiting the maximum anodic potential to grow a stable oxide on the alloy. On the other hand, a large anodic potential range can be swept for the alloy in the $\mathrm{Na}_{2} \mathrm{SO}_{4}$ solution (Figure 5 b). In this electrolyte solution, it is possible to grow oxide films up to much more positive potentials without film rupture ${ }^{27}$ hence these films were grown up to $E_{\mathrm{F}}$ equal to $7.0 \mathrm{~V}$. As already reported for Ti alone, ${ }^{3,29}$ Figure 5(b) shows a typical valve metal behavior for the Ti-50Zr at.\% alloy too, and its anodic oxide grows according to the high-field model (Equation 1) in this less aggressive electrolyte. Thus, it was possible to compare the chemical and mechanical stability of the oxides grown in the presence of chloride ions and in their absence.

Table 1 lists the values of $R R$ obtained for the films grown in $\mathrm{Na}_{2} \mathrm{SO}_{4}$ on $\mathrm{Zr}$ and its alloys. Contrary to the case of the oxide films grown in the Ringer solution, the smaller value of $R R$ occurs for the oxide film grown on the Ti-50Zr at.\% alloy. The value for the $\mathrm{Zr}-2.5 \mathrm{Nb}$ wt.\% alloy is similar to the ones
Table 1. Reconstruction rates $(R R)$ for the oxides grown on the various materials in $0.1 \mathrm{~mol} \mathrm{~L}^{-1} \mathrm{Na}_{2} \mathrm{SO}_{4}$ up to $7 \mathrm{~V}$, left at open circuit in the Ringer physiological solution and reconstructed in the $\mathrm{Na}_{2} \mathrm{SO}_{4}$ solution

\begin{tabular}{lccc}
\hline Material & $\mathrm{Zr}$ & $\mathrm{Zr}-2.5 \mathrm{Nb}$ & $\mathrm{Ti}-50 \mathrm{Zr}$ \\
\hline$R R / \%$ & 6.1 & 3.2 & 0.44 \\
\hline
\end{tabular}

previously obtained for films grown in the presence of chloride ions, while the value for $\mathrm{Zr}$ is higher, being approximately twice the previously obtained ones. On the other hand, $R R$ for the Ti-50Zr at.\% alloy is significantly smaller than the ones previously obtained. Hence, clearly the oxide film grown in $\mathrm{Na}_{2} \mathrm{SO}_{4}$ on the Ti-containing alloy presents less mechanical instabilities than the one grown in the Ringer solution. This indicates that $\mathrm{Ti}$ is more sensitive to the nature of the electrolytic solution during the anodization process, possibly due to incorporation of species ${ }^{23,24}$ from the electrolyte, as well as reinforces the data discussed above showing that the aging with the potential (i.e. with $E_{F}$ ) affects more strongly the solid-state properties of Ti oxides. ${ }^{30}$

\section{Conclusions}

The electrochemical data presented on the growth and stability of anodic oxides that passivate $\mathrm{Zr}$ and the alloys $\mathrm{Zr}-2.5 \mathrm{Nb}$ wt.\% and Ti-50Zr at.\% showed that either the electrolytic medium where they are grown or the method used for anodization have significant influence on both their growth and stability. The anodization rate for the two alloys in the Ringer solution is higher than the one for $\mathrm{Zr}$, indicating that the addition of the alloying elements $\mathrm{Ti}$ and $\mathrm{Nb}$ to zirconium is positively affecting the rate of formation of the anodic oxide. The potentiostatic aging of the oxide films was found to significantly increase the stability of the anodic oxide films. Furthermore, the anodic formation of the oxide film in an electrolytic solution free of chloride ions, $0.1 \mathrm{~mol} \mathrm{~L}^{-1} \mathrm{Na}_{2} \mathrm{SO}_{4}$, led to a significant decrease in the reconstruction rate of the oxide grown on the Ti-50Zr at.\% alloy. On the other hand, the anodic growth in the $\mathrm{Na}_{2} \mathrm{SO}_{4}$ solution allows a greater corrosion protection of the materials to be attained, since a much thicker oxide layer can be grown; thus, prepassivation of these metals in an electrolytic solution free of chloride ions seems to be a viable way of improving their protection against corrosion.

\section{Acknowledgements}

The authors are grateful to FAPESP and CNPq for scholarships and grants that made this work possible. 


\section{References}

1. D’Alkaine, C. V.; Souza, L. M. M. de ; Nart, F. C.; Corros. Sci. 1993, 34, 117 .

2. Lohrengel, M. M.; Electrochim. Acta 1994, 39, 1265.

3. Marino, C. E. B.; Oliveira, E. M. de; Rocha-Filho, R. C.; Biaggio, S. R.; Corros. Sci. 2001, 43, 1465.

4. Young, L; Anodic Oxide Films, Academic Press: London, 1962.

5. Kolman, D.G.; Scully, J.R.; J. Electrochem. Soc. 1995, 142, 2179.

6. Patrito, E.M.; Torresi, R.M.; Leiva, E.P.M.; Macagno, V.A.; J. Electrochem. Soc. 1990, 137, 524.

7. Bjursten, L. M.; Emanuelsson, L.; Ericson, L. E.; Thomsen, P.; Lausmaa, J.; Mattson, L.; Rolander U.; Kasemo B.; Biomaterials 1990, 11, 596.

8. Okazaki, Y.; Rao, S.; Tateishi, T.; Ito, Y.; Mater. Sci. Eng. 1998, $A 243,250$.

9. Niinomi, M.; Kuroda, D.; Fukunaga, K.; Morinaga, M.; Kato, Y.; Yashiro, T.; Suzuki, A.; Mater. Sci. Eng. 1999, A263, 193.

10. Pourbaix, M.; Biomaterials 1984, 5, 122.

11. Wang, K.; Mater. Sci. Eng. 1996, A213, 134.

12. Kobayashi, E.; Matsumoto, S.; Yoneyama, T.; Hamanaka, H.; J. Biomed. Mater. Res. 1995, 29, 943.

13. Khan, M. A.; Williams, R. L.; Williams, D. F.; Biomaterials 1999, 20, 631 .

14. Halley-Demoulin, I.; Valot, C.; Ciosmak, D.; Lallemant, M.; Heizmann, J. J.; Laruelee, C.; Mater. Sci. Forum 1994, 157 $162,521$.

15. Yu, S.Y.; Scully, J.R.; Vitus, C. M.; J. Elecrochem. Soc. 2001, $148, \mathrm{~B} 68$.

16. Oliveira, N. T. C.; Rocha-Filho, R. C.; Biaggio, S. R.; Abstracts of the XIV Congress of the Iberoamerican Electrochemical Society, Oaxaca, Mexico, 2000. Abstract SUP-035.
17. Arvía, A.J.; Israel J. Chem. 1979, 18, 89.

18. Maurice, V; Yang, W.P.; Marcus, P.; J. Electrochem. Soc. 1996, 143,1182 .

19. Marcus, P.; Electrochim. Acta 1998, 43, 109.

20. D’Alkaine, C.V.; Boucherit, M.N.; J. Electrochem. Soc. 1997, 144,3331

21. D’Alkaine, C. V.; Souza, L. M. M. de ; Nart, F. C.; Corros. Sci. 1993, 34, 129

22. Blackwood, D.J.; Peter, L.M.; Williams D.E.; Electrochim. Acta 1988, 33, 1143.

23. Ferdjani, S.; David, D.; Beranger, G.; J. Alloys Compd. 1993, 200, 191.

24. Marino, C. E. B.; Nascente, P. A. P.; Rocha-Filho, R. C.; Biaggio, S. R.; Braz. J. Vacuum Appl. 1999, 18, 44.

25. Di Quarto, F.; Piazza, S.; Sunseri, C.; J. Electrochem. Soc. 1984, 131, 2901.

26. Leach, J.S.L.; Pearson, B.R.; Electrochim. Acta 1984, 29, 1271.

27. Oliveira, N. T. C.; Biaggio, S. R.; Rocha-Filho, R. C.; Bocchi, $\mathrm{N}$.; unpublished work.

28. Kawashima, A.; Yu, W. P.; Zhang, B. P.; Habazaki, H.; Asami, K.; Hashimoto, K.; Mater. Trans. 1997, 38, 443.

29. Oliveira, E. M. de; Marino, C. E. B.; Rocha-Filho, R. C.; Biaggio, S. R.; Electrochem. Commun. 2000, 2, 254.

30. Blackwood, D.J.; Peter, L.M.; Electrochim. Acta 1989, 34, 1505

Received: January 17, 2002

Published on the web: July 10, 2002

FAPESP helped in meeting the publication costs of this article. 